\title{
Thyroid Cancer pT4b TNM Finding v6
}

National Cancer Institute

\section{Source}

National Cancer Institute. Thyroid Cancer pT 4b TNM Finding v6. NCI Thesaurus. Code C60867.

Thyroid cancer with any size tumor invading the prevertebral fascia, or encasing the carotid artery or mediastinal vessels. 